\title{
The Antioxidant Activity of Sterculia stipulata Korth Woods and Leaves by FRAP Method
}

\author{
Rini Prastiwi ${ }^{1,2}$, Berna Elya ${ }^{1, *}$, Muhammad Hanafi ${ }^{3,4}$, Yesi Desmiaty ${ }^{2}$, Rani Sauriasari ${ }^{5}$
}

Rini Prastiwi ${ }^{1,2}$, Berna Elya ${ }^{1, *}$, Muhammad Hanafi, ${ }^{3,4}$, Yesi Desmiaty $^{2}$, Rani Sauriasari ${ }^{5}$

'Department of Pharmacognosy and Phytochemistry, Faculty of Pharmacy Universitas Indonesia, Depok 16424, West Java, INDONESIA.

${ }^{2}$ Department of Pharmacognosy and Phytochemistry, Faculty of Pharmacy and Science Muhammadiyah Prof. Dr. Hamka University, 1340 Jakarta, INDONESIA. ${ }^{3}$ Research Center for Chemistry, Indonesian Institute of Science, Serpong (LIPI Indonesia), INDONESIA.

${ }^{4}$ Department of Pharmacognosy

Phytochemistry, Faculty of Pharmacy

Universitas Pancasila, Jakarta, West Java, INDONESIA.

${ }^{5}$ Department of Pharmacology, Faculty of Pharmacy Indonesia University, Depok 16424, West Java, INDONESIA.

\section{Correspondence}

\section{Berna Elya}

Department of Pharmacognosy and

Phytochemistry, Faculty of Pharmacy

Universitas Indonesia, Depok 16424, West Java, INDONESIA.

E-mail: Berna.elya@gmail.com

History

- Submission Date: 20-11-2019.

- Review completed: 05-12-2019;

- Accepted Date: 18-12-2019.

DOI : 10.5530/pj.2020.12.36

Article Available online

http://www.phcogj.com/v12/i2

\section{Copyright}

(C) 2020 Phcogj.Com. This is an openaccess article distributed under the terms of the Creative Commons Attribution 4.0 International license.

\section{ABSTRACT}

Background: Phenol compounds and flavonoids are known have antioxidant activity. Sterculia genus has secondary metabolite rich of phenols and flavonoids. Objective: The aim of this study of the activity antioxidants of Sterculia stipulata Korth. Woods and leaves by FRAP method. Materials and methods: Extraction done using n-hexane, ethyl acetate, and methanol. The methanol extract was determined antioxidant activity using the FRAP method and also determined the total phenols content, total flavonoids, and phytochemical screening. Results: The antioxidant activity of wood extract was $4.74 \pm 1.03 \mathrm{FeEAC}$ (mol/g) while leaves extract $41.17 \pm 1.99 \mathrm{FeEAC}(\mathrm{mol} / \mathrm{g})$. Total phenols content for wood extract $16.46 \pm 3.51 \mathrm{mg}$ $\mathrm{GAE} / \mathrm{g}$, for leaves extract $141.62 \pm 10.54 \mathrm{mg} \mathrm{GAE} / \mathrm{g}$. The total flavonoids content for woods extract was $27.99 \pm 0.62 \mathrm{mg} \mathrm{QE} / \mathrm{g}$ for leaf extract $41.45 \pm 5.83 \mathrm{mg} \mathrm{QE} / \mathrm{g}$. The compounds of woods and leaves are the same; it is consist of terpenoids, alkaloids, phenols, flavonoids, saponins, terpenoids, and negatives for anthraquinone. Conclusion: The antioxidant activity of the leaves of Sterculia stipulata Korth. is greater than its wood activities.

Keywords: Antioxidant; Sterculia stipulata Korth.; FRAP; Phenols; Flavonoids

\section{INTRODUCTION}

The genus Sterculia rich of metabolite secondary flavonoids and phenolic compounds. The phenolic compounds such as phenolic acid, propanoic phenyl, coumarins, lignans, and lignin with much smaller amounts than flavonoids. ${ }^{1}$ The ironreducing antioxidant power (FRAP) test was a method used to determine antioxidant activity by reducing $\mathrm{Fe}$ (III) to Fe (II) by complexation with 2,4,6-Tripyridyl-s-Triazine (TPTZ). The test is carried out at acidic $\mathrm{pH} 3,6$ to maintain iron solubility. ${ }^{2}$ FRAP value obtained with comparing changes in the absorption of the test mixture at $593 \mathrm{~nm}$ with the mixture, which contains Ferro ions whose concentration is known. ${ }^{3-5}$ The FRAP test based on electron transfer. FRAP cannot detect compounds that work by radical reduction (hydrogen transfer). Method FRAP testing is simple, fast, inexpensive, and requires no special equipment. ${ }^{2}$ In this study, the antioxidant activity of S. Stipulata determined. Antioxidants play an important role in the prevention and treatment of metabolic disorders caused by oxidative stress. ${ }^{6}$ Some sterculia genus plants are known to have antioxidant activity, including methanol extract Sterculia foetida stems with $\mathrm{IC}_{50}$ values of $20 \mu \mathrm{g} /$ $\mathrm{ml} .{ }^{7}$ Sterculia villosa bark ethyl acetate fraction with IC $_{50} 23.99 \mu \mathrm{g} / \mathrm{ml}^{8}$

\section{MATERIALS AND METHODS}

\section{Material}

TPTZ (2,4,6-tripyridyl-s-triazine) from Sigma (Singapore), Hexane pa, ethyl acetate pa, and methanol pa from Sigma ( Singapore). Solvent from local supplier. Quercetine from Sigma (Singapore). Sterculia stipulata leaves and woods from Botanical Garden of Bogor and determined in Botany Herbarium Research Institute, Cibinong, West Java. The voucher specimen fot Sterculia stipulata VIII.G.199.

\section{Extraction}

Woods and leaves of Sterculia stipulata extracted by n-hexane, ethyl acetate, and the final solvent was methanol. Extraction by maceration method. The methanol extract identified the antioxidant activity and also the phenols total and flavonoids total.

\section{Antioxidant activity with FRAP}

The antioxidant activity with the FRAP method for sample preparation was carried out by five (5) $\mathrm{mg}$ sample (extract/quercetine) of $5 \mathrm{mg}$ dissolve in 2 $\mathrm{ml}$ methanol p.a, (Concentration to $2500 \mu \mathrm{g} / \mathrm{ml}$ ). From The stock made different concentration for determined FeEAC. Piping $30 \mu \mathrm{l}$ samples into the well. The sample dissolved in methanol. Then added $270 \mu \mathrm{L}$ FRAP (reagents Buffer: TPTZ: FeCl3.6H2O $=10: 1: 1$ ) shaken and incubated at $37^{\circ} \mathrm{C}$ for $30 \mathrm{~min}$. The absorbance measured at a wavelength of 593 $\mathrm{nm}$. As a blank methanol used to replace the sample, which contains of $30 \mu \mathrm{l}$ methanol and $270 \mu \mathrm{l}$ FRAP reagent. The plate blank contains methanol $300 \mu \mathrm{l}$. FRAP reagent $=10: 1: 1$ reagent (buffer acetate: TPTZ: $\mathrm{FeCl} 3.6 \mathrm{H} 2 \mathrm{O}$ ). The standard curve uses AFS. This method refers to the research of Pereira et al. and Wong et al. ${ }^{9,10}$

AFS solution as a calibration curve. AFS standard solution used $1.200 \mu \mathrm{M}$. The AFS solution was diluted and stocked with various concentration $(1200 ; 600 ; 300 ; 150 ; 75$; and $37.5 \mu \mathrm{M})$. The formula used to calculate antioxidant activity is according to Wong et al. 


$$
F e E A C=\frac{\Delta \mathrm{A}}{G R A D} \times \frac{A v}{S p v} \times D \times \frac{1}{C e x t} \times 10^{5}
$$

Based on the formula, FeEAC was the equality of ferric ions with antioxidant activity $(\mu \mathrm{mol} / \mathrm{g}) . \Delta \mathrm{A}=$ absorbance of samples that have been reduced by blank. GRAD $\left(\mathrm{M}^{-1}\right)$ was the gradient of the AFS calibration graph. Av = total volume for the test $(300 \mu \mathrm{l}), \mathrm{Spv}=$ sample volume $(30 \mu \mathrm{l}), \mathrm{C}_{\text {ext }}=$ concentration of sample stock, weight (gram) in volume $(\mathrm{g} / \mathrm{l}), \mathrm{D}=$ dilution factor for sample before analysis $(\mathrm{D}=1$ if sample not diluted). GRAD (gradient) determined from the calibration curve on AFS.

\section{Determination of total flavonoids content}

The total flavonoids content determined by the method described by Farasat et al. ${ }^{11}$ Twenty (20) $\mu \mathrm{l}$ of methanol extract added with $20 \mu \mathrm{L}$ of added $\mathrm{AlCl} 3.6 \mathrm{H} 2 \mathrm{O} 10 \%$, then $20 \mu \mathrm{l}$ sodium acetate $1 \mathrm{M}$ and 180 $\mu \mathrm{l}$ aquadest. The solution was shaken 60 seconds and incubated at room temperature for $30 \mathrm{~min}$. The color intensity read at $415 \mathrm{~nm}$. The concentration of the sample was $100 \mu \mathrm{g} / \mathrm{ml}$. As a blank, $\mathrm{AlCl}_{3}$ replaced with aquadest. The calibration curve used was quercetine. The total flavonoids determined as equality with quercetine (mg QE/gram). The calibration curve used quercetine, and treatment was the same as the sample, only replaced with quercetine in various variations $(100 ; 50 ; 25$; $12.5 ; 6.25 ; 3.75 \mu \mathrm{g} / \mathrm{ml})$.

\section{Determination of total phenols content}

The total phenol content in the extract determined using the method from Farasat et al., with slight modifications. Twenty (20) $\mu$ l of extract was added with $100 \mu \mathrm{L}$ of Folin-C Reagent (1:10), shaking for 60 seconds and allowed to stand for 4 minutes. Added with $80 \mu$ l solution of Sodium carbonate $\left(\mathrm{Na}_{2} \mathrm{CO}_{3}\right) 7.5 \%$ in water, shaking for $60 \mathrm{~s}$. This mixture was incubated at room temperature in a dark place for 2 hours. Furthermore, it read at $600 \mathrm{~nm}$. The concentration of extract in the sample made at $100 \mu \mathrm{g} / \mathrm{ml}$. The concentration of stock solutions was $1000 \mu \mathrm{g} / \mathrm{ml}$. Blank was samples replaced with methanol. The treatment was the same as sample. In total phenols determination using gallic acid as the standard, total phenols calculated as equality of gallic acid (mg GAE/gram).

\section{RESULTS AND DISCUSSION}

\section{Total phenols compound}

Determination of total phenols content in the methanol extract of wood and leaves of Sterculia stipulata showed that the total phenols content in wood was greater than that found in the leaves. The results showed in Table 1.

\section{Flavonoids compound}

Determination of total flavonoids levels in Sterculia stipulata results in greater flavonoids content in leaves compared to wood. The results showed in Table 2.

\section{Antioxidant activity with FRAP (Ferric reducing antioxidant power)}

In testing antioxidant activity using the FRAP method using the AFS comparison. The results of the regression curve for AFS standard chart results shown in the Figure 1.

The antioxidant activity with the FRAP method gives the results that wood extract has a greater activity compared leaves extract $41.17 \pm 1.99$ $\mathrm{FeEAC}(\mathrm{mol} / \mathrm{g})$, while for woods it was $4.74 \pm 1.03 \mathrm{FeEAC} \mathrm{(mol} / \mathrm{g})$. This value is still far compared to the positive control quercetine of 1201.61 $\pm 77.89 \mathrm{FeEAC}$ (mol/g). The antioxidant activity showed on Table 3.
Table 1: Phenols total of Sterculia stipulata woods and leaves.

\begin{tabular}{cccc}
\hline No & Extract & $\begin{array}{c}\text { Phenols total } \\
(\mathrm{mg} \mathrm{GAE} / \mathrm{g}) \text { extract }\end{array}$ & kv \\
\hline 1 & Leaves & $141.62 \pm 10.54$ & 16.47 \\
2 & Woods & $16.46 \pm 3.51$ & 10.70 \\
\hline
\end{tabular}

Table 2: Flavonoids total of Sterculia stipulata woods and leaves.

\begin{tabular}{cccc}
\hline No & Extract & $\begin{array}{c}\text { Flavonoids Total } \\
(\text { mg QE/g) Extract }\end{array}$ & kv \\
\hline 1 & Leaves & $41.45 \pm 5.83$ & 9.60 \\
2 & Woods & $27.99 \pm 0.62$ & 14.69 \\
\hline
\end{tabular}

Table 3: Antioxidant activity with FRAP.

\begin{tabular}{ccc}
\hline Extracts & Antioxidant Activity FeEAC (mol/g) & kv \\
\hline Leaves & $41.17 \pm 1.99$ & 5.42 \\
Woods & $4.74 \pm 1.03$ & 3.67 \\
Quercetine & $1201.61 \pm 77.89$ & 6.48 \\
\hline
\end{tabular}

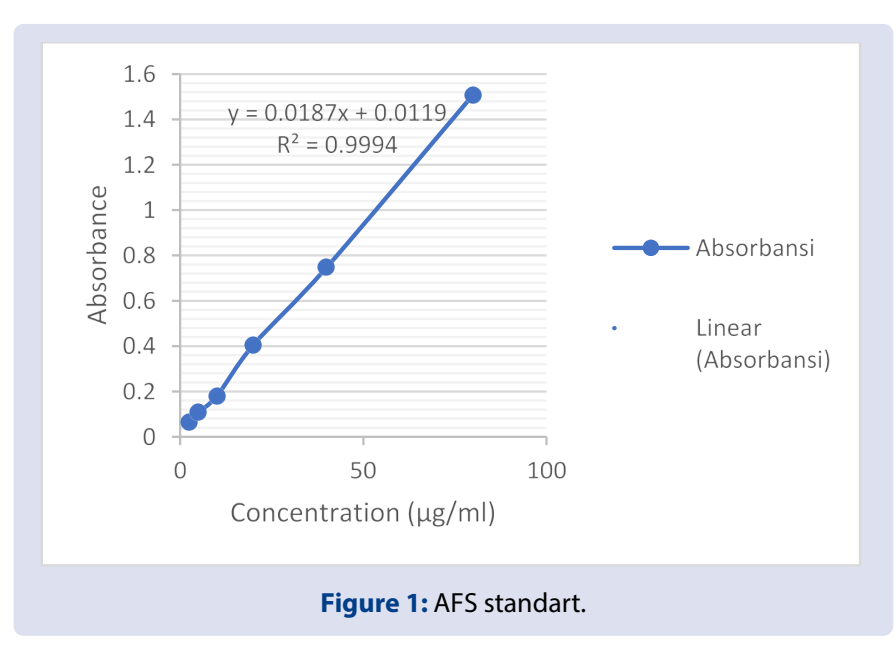

\section{Phytochemical screening}

Identification of the content of chemical compounds is carried out on terpenoids/steroids, alkaloids, tannins, flavonoids, saponins and anthraquinones. The results of their identification showed on Table 4.

For the result of chemical content showed that there is no differences between woods and leaves.

The FRAP test based on the ability of the phenol to reduce the yellow color of ferric tripyridyltriazine (Fe (III) -TPTZ) to the blue color of the Ferro (Fe (II) -TPTZ complex) by antioxidant activity that contributes to electrons. The blue color produced was measured spectrophotometrically at 593. Ferric salt used as an oxidant and its redox potential $(<0.70 \mathrm{~V})$. The FRAP test required an acidic condition (non-physiological, low $\mathrm{pH}$ value $=3.6$ ) to maintain iron solubility. One FRAP unit defined as a reduction of $1 \mathrm{~mol}$ of $\mathrm{Fe}$ (III) to $\mathrm{Fe}$ (II)). ${ }^{10,12}$ The advantages of FRAP Test are simple, fast, cheap, and strong and do not require special equipment. FRAP tests can done using automatic, semiautomatic, or manual methods. ${ }^{2} \mathrm{Fe}$ (II) was a prooxidant that can react with $\mathrm{H}_{2} \mathrm{O}_{2}$ to produce hydroxyl radicals $\left(\mathrm{OH}^{-}\right)$, dangerous free radicals found in vivo. The ability of compounds to produce $\mathrm{Fe}$ (II) from $\mathrm{Fe}$ (III) is defined as "antioxidant strength" in the FRAP test. The ability to reduce $\mathrm{Fe}$ (III) is possible reflecting the ability to reduce reactive species. However, not all reductants capable of reducing Fe (III) are antioxidant. ${ }^{13-15}$ The total phenols, total flavonoids and antioxidant activity in leaves better than woods. Phenols and flavonoids have an antioxidant activity. ${ }^{11}$ 
Table 4: Identification chemical compound of Sterculia stipulata extract.

\begin{tabular}{lcc}
\hline \multicolumn{1}{c}{ Chemical compound } & leaves & Woods \\
\hline Terpenoids/steroids & Terpenoid + & Steroid + \\
Alkaloids & + & + \\
$\quad$ Dragendorff & + & + \\
$\quad$ Mayer & & + \\
Tanins & + & + \\
$\quad$ FeCl3 & + & + \\
$\quad$ Folin & + & + \\
$\quad$ Gelatine & + & - \\
Flavonoids & - & + \\
Antraquinons & + & \\
Saponins & &
\end{tabular}

Note $:+=$ presence, $-=$ absence

\section{CONCLUSION}

The leaves of Sterculia stipulata have an antioxidant activity better than woods, and total phenols and flavonoids total more higher than the woods.

\section{CONFLICT OF INTEREST}

All the authors declare there is no conflict of interest.

\section{ABBREVIATIONS}

S: Sterculia; TPTZ : 2,4,6-tripyridyl-s-triazine; FRAP : Ferric Reducing Antioxidant Power; AFS : Ammonium ferrous sulfate

\section{REFERENCES}

1. El-Sherei MM, Ragheb AY, Kassem MS, Marzouk MM, Mosharrafa SA, Megied Saleh NA. Phytochemistry, biological activities and economical uses of the genus Sterculia and the related genera: A reveiw. Asian Pacific J Trop Dis. 2016;6(6):492-501.
2. El-Mas MM, Mohy El-Din MM, El-Gowilly SM, Sharabi FM. Relative roles of endothelial relaxing factors in cyclosporine-induced impairment of cholinergic and $\beta$-adrenergic renal vasodilations. Eur J Pharmacol. 2004;487(1-3):149-58 .

3. Benzie IFF, Strain JJ. The ferric reducing ability of plasma (FRAP) as a measure of antioxidant power: The FRAP assay. 1996;76:70-6.

4. Benzie IFF, Szeto YT, Africa N. Total antioxidant capacity of teas by the ferric reducing/antioxidant power assay. J Agric Food Chem. 2000:633-6.

5. Szeto YT, Tomlinson B, Benzie IFF. Total antioxidant and ascorbic acid content of fresh fruits and vegetables: Implications for dietary planning and food preservation. Br J Nutr. 2002:55-9.

6. Patrignani M, Juan G, Ángel J, Elena C. Antioxidant capacity of Maillard reaction products in the digestive tract: An in vitro and in vivo study. Food Chemistry 2019;276:443-50.

7. Swarnalatha $\mathrm{K}$, Venkata $\mathrm{CH}$, Babu K, Babu BH. Phytochemical screening, antidiabetic and anti-oxidant activities of Kigelia africana (LAM.) and Sterculia foetida L. Rasayan Journal of Chemistry. 2019;12:(2):907-14.

8. Uddin Z, Bin Emran T, Nath AK, Hossain I, Alamgir M. In vitro Antioxidative Fibrinolytic and Phytochemical Effects of Different Extracts of Sterculia villosa Barks. Int J Res Pharm Biosci. 2015;2(1):1-9

9. Figueira JA, Pereira JAM, Porto-figueira P, Câmara JS. Ultrasound-assisted liquid-liquid extraction followed by ultrahigh pressure liquid chromatography for the quanti fi cation of major carotenoids in tomato. J Food Compos Anal. 2017; 57:87-93

10. CwW, Wsm C, Yy L, De B, Aas T. A FRAP Assay at $\mathrm{pH} 7$ unveils Extra antioxidant activity from green, black, white and rooibos tea but not apple tea. Food Nutr Rep. 2015;1(1):1-8.

11. Farasat M, Khavari-nejad R. Antioxidant activity, total phenolics and flavonoid contents of some edible green seaweeds from northern coasts of the persian Gulf. Iran J Pharm Res. 2014;13(1):163-70.

12. Karadag A, Ozcelik B, Saner S. Review of methods to determine antioxidant capacities. Food Anal Methods. 2009;2(41):41-60.

13. Angelica A, De SB, Henderson T, Nigam PS, Owusu-apenten RK. Short communication A universally calibrated microplate ferric reducing antioxidant power (FRAP) assay for foods and applications to Manuka honey. FOOD Chem. 2015;174:119-23.

14. Abu Bakar MF, Ismail NA, Isha A, Mei Ling AL. Phytochemical Composition and biological activities of selected wild berries (Rubus moluccanus L., $R$ fraxinifolius Poir., and R. alpestris Blume), evidence-based complement. Altern Med. 2016:1-10

15. Du B, Xu B. Oxygen radical absorbance capacity (ORAC) and ferric reducing antioxidant power (FRAP) of $\beta$-glucans from different sources with various molecular weight. Bioact Carbohydrates Diet Fibre. 2014:3(1):11-6.

\section{GRAPHICAL ABSTRACT}

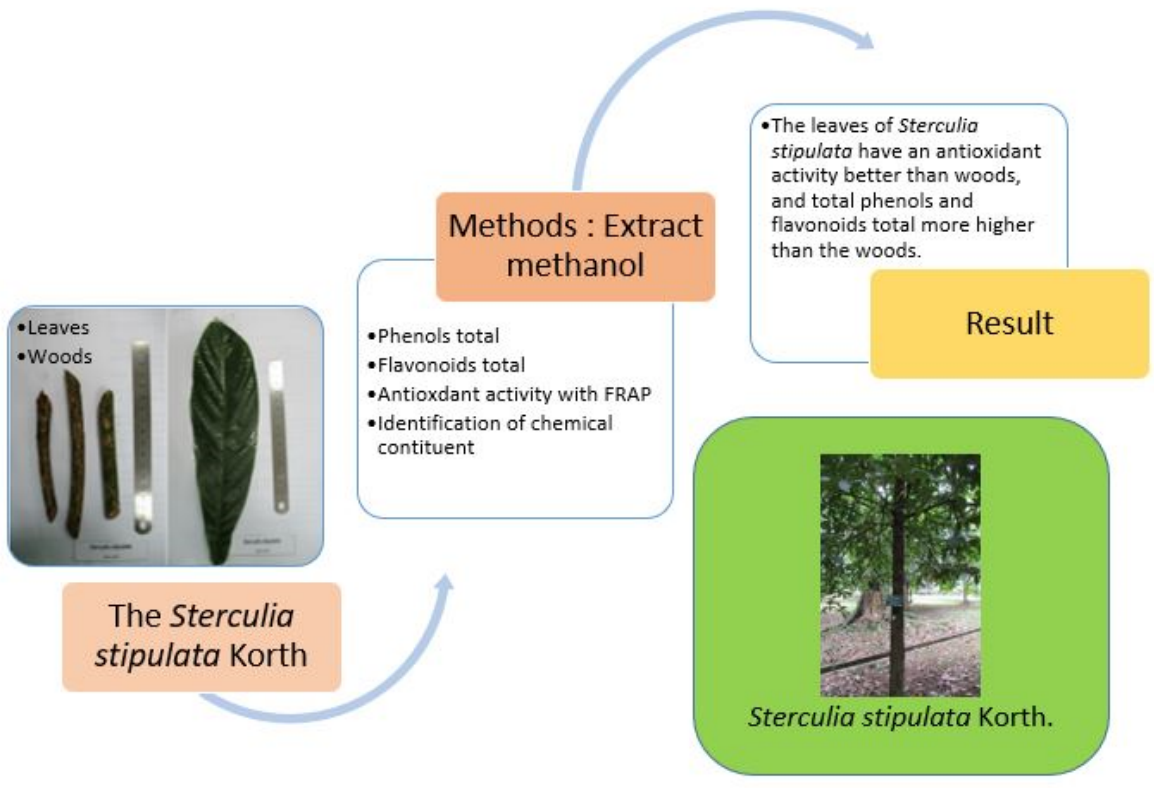




\section{ABOUT AUTHORS}

Rini Prastiwi: Lecturer and researcher at Faculty of Pharmacy and Sciences, Universitas Muhammadiyah Prof. Dr. Hamka, Klender, Jakarta 13460, Indonesia, and student at Faculty of Pharmacy, Universitas Indonesia.

Berna Elya: Lecturer and researcher at Faculty of Pharmacy Universitas Indonesia, Depok 16424, West Java, Indonesia.

Rani Sauriasari: Lecturer and researcher at Faculty of Pharmacy Universitas Indonesia, Depok 16424, West Java, Indonesia.

Muhammad Hanafi: Researcher at Research Center for Chemistry, Indonesian Institute of Science, Serpong, (LIPI) Indonseia and lecturer at Faculty of Pharmacy Universitas Pancasila, Depok, West Java, Indonesia.

Yesi Desmiaty: Lecturer and researcher at Faculty of Pharmacy Universitas Pancasila, Depok, West Java, Indonesia and student at Faculty of Pharmacy, Universitas Indonesia.

Cite this article: Prastiwi R, Elya B, Hanafi M, DesmiatyY, Sauriasari R. The Antioxidant Activity of Sterculia stipulata Korth Woods and Leaves by FRAP Method. Pharmacog J. 2020;12(2):236-9. 